\title{
PERANCANGAN SISTEM INFORMASI TRAINING PADA PUSAT PENDIDIKAN DAN PELATIHAN PT. SUMALINDO LESTARI JAYA
}

\author{
Sugiyono \\ IAIN Samarinda \\ sugiyono@iain-samarinda.ac.id
}

\begin{abstract}
Information technology is growing rapidly has an impact on changing paradigms and ways of working that are widely applied by most organizations today. As a company engaged in the plywood industry, PT. Sumalindo Lestari Jaya, Tbk has and employs thousands of employees in it. It has problems related to human resource development, but so far the management is still conventional. The problems that occur start from participant registration, participant selection and monitoring, participant tracking, placement of work positions according to employee competency and expertise, untidy filing systems, activity evaluation, to the distribution of training allocations per section and per employee. This is what makes the researcher interested in doing this study. The method used is Research and Development $(R \& D)$ in the form of software design that produces Information Systems as a tool in managing training. The result of this research is a Training Information System software which is used to assist the management of education and training activities starting from participant selection activities, activity scheduling, implementation administrative governance, budget planning and financing, to evaluation and reporting activities. System testing and implementation was carried out on 20 training participants by comparing the results before and after the system was implemented. Based on comparative data on management patterns before and after using the system, it can be concluded that the Training Information System can increase efficiency and effectiveness in managing training activities.

Keywords: Information Systems, Research and Development, Training
\end{abstract}

Abstrak: Teknologi informasi yang berkembang pesat berdampak pada perubahan paradigma dan cara kerja yang banyak diterapkan oleh sebagain besar organisasi dewasa ini. Sebagai perusahaan yang bergerak dibidang industri kayu lapis PT. Sumalindo Lestari Jaya, Tbk. memiliki dan mempekerjakan ribuan karyawan didalamnya memiliki problematika terkait pengembangan sumber daya manusia, namun sejauh ini pengelolaannya masih konvensional. Permasalahan yang terjadi dimulai dari pendaftaran peserta, seleksi dan monitoring peserta, pelacakan peserta, penempatan posisi kerja sesuai bidang kompetensi dan keahlian karyawan, sistem filing yang kurang rapi, evaluasi kegiatan, sampai dengan masalah distribusi alokasi training per bagian dan per karyawan. Hal inilah yang melatar belakangi penelitian ini menarik untuk dilakukan. Adapun metode yang digunakan adalah Research and Development (R\&D) dalam bentuk rancangan software yang menghasilkan Sistem Informasi sebagai alat bantu dalam mengelola training. Hasil dari penelitian ini adalah sebuah perangkat lunak Sistem Informasi Training yang digunakan dalam membantu pengelolaan kegiatan pendidikan dan pelatihan mulai dari kegiatan seleksi calon peserta, penjadwalan kegiatan, tata kelola administrasi pelaksanaan, perencanaan anggaran dan pembiayaan, sampai dengan evaluasi dan kegiatan pelaporan. Uji coba dan implementasi sistem dilakukan pada 20 peserta training dengan membandingkan hasil sebelum dan setelah diterapkan sistem. Berdasarkan data perbandingan pola pengelolaan sebelum dan setelah menggunakan sistem dapat disimpulkan bahwa Sistem Informasi Training dapat meningkatkan efisiensi dan efektifitas dalam mengelola kegiatan training.

Kata kunci: Sistem Informasi, Research and Development, Training 


\section{Pendahuluan}

Perkembangan teknologi informasi dan sosial media yang demikian pesat berdampak pada perubahan paradigma dan cara kerja yang banyak diterapkan oleh sebagain besar organisasi dewasa ini. Metode konvensional yang serba manual tentu bukan solusi yang tepat. Sebagai perusahaan yang bergerak dibidang industri kayu lapis PT. Sumalindo Lestari Jaya, Tbk. memiliki dan mempekerjakan ribuan karyawan didalamnya, tentu terus berusaha mampu menjaga kualitas produknya untuk semakin kompetitif dari waktu ke waktu.

Dalam upaya tersebut selain faktor produk dan faktor layanan, faktor proses juga menjadi penting untuk mendapat perhatian manajemen perusahaan dalam hal ini. Perusahaan ini telah memiliki unit tersendiri yang mengurus terkait pengembangan sumber daya manusia, namun sejauh ini pengelolaannya masih konvensional, sehingga berbagai problematika muncul disana sini, mulai dari pendaftaran peserta, seleksi dan monitoring peserta, pelacakan peserta, penempatan posisi kerja sesuai bidang kompetensi dan keahlian karyawan, sistem filing yang kurang rapi, evaluasi kegiatan, sampai dengan masalah distribusi alokasi training per bagian dan per karyawan. Hal inilah yang melatar belakangi penelitian ini menarik untuk dilakukan.

Saat ini pemanfaatan sistem informasi tidak hanya semata-mata berorientasi pada profit perusahaan semata, akan tetapi dapat juga digunakan untuk mengembangkan sumber daya manusia yang dimiliki oleh perusahaan. Pengembangan sumber daya manusia dapat dilakukan dengan adanya pelatihanpelatihan secara intensif. Oleh karenanya selayaknya diperusahaan ini memanfaatkan Sistem Informasi Training diperlukan karena masih minimnya penyampaian informasi pelatihan kepada karyawan (Asari \& Andriana, 2017).

Dalam penelitian sejenis yang pernah dilakukan pada Balai Besar Pelatihan Kesehatan (BBPK) Ciloto disimpulkan bahwa dengan pemanfaatan Sistem Informasi dalam mengelola kegiatan training dapat memudahkan kegiatan administrasi dalam penyelenggaraan kegiatan pelatihan khususnya dalam proses registrasi peserta, serta proses pengolahan, distribusi dan komunikasi melalui Sistem secara terintegrasi antar unit kerja dapat dilakukan dengam cepat dan terdokumentasi dengan baik (Setiani, 2018).

Pada peneletian lainnya dapat disimpulkan bahwa Sistem Informasi Training dengan berbasis website pada sebuah perusahaan Startup dapat berjalan dengan baik dengan hasil pengujian dari sistem dinyatakan layak dan secara fungsional sistem dapat menghasilkan output yang diharapkan. Penerapan sistem ini juga mempermudah dalam proses integrasi data yang dapat dilakukan secara terpusat (Nathanael \& Somya, 2019).

Dari berbagai data empiris tersebut maka peneliti akan fokus pada kajian bagaimana merancang sebuah Sistem informasi Training sesuai dengan karakteristik dan kebutuhan perusahaan. Adapun tujuan dari penelitian ini adalah dalam rangka menemukan hambatan dalam tata kelola pendidikan dan pelatihan terhadap karyawan perusahaan pada Departemen Pusdiklat, dan mencari solusi melalui kegiatan analisis dan pengembangan produk sistem informasi.

\section{Metode}

Metode yang digunakan pada penelitian ini adalah menggunakan metode Research and Development $(R \& D)$, target penelitian untuk menghasilkan rancangan produk aplikasi training yang dapat diuji manfaat dan 
efektifitasnya (Sugiyono, 2016). Dimana detail pengerjaannya adalah sebagai berikut:

\section{Waktu dan Tempat Penelitian}

Pada penelitian ini mengambil studi kasus pada Departemen Pusat Pendidikan dan Pelatihan (Pusdiklat) PT. Sumalindo Lestari Jaya, Tbk. selama 6 bulan mulai dari bulan Nopember 2019 s/d bulan April 2020.

\section{Pendekatan}

Pendekatan dalam perancangan sistem informasi training ini adalah waterfall yakni dengan membagi pekerjaan perancangan ke dalam beberapa fase/tahapan, Yurindra (2017:43).

\section{Subjek Penelitian}

Subyek dalam kegiatan penelitian ini berjumlah 10 orang terdiri dari 1 orang kepala departemen dan 5 orang staf dari departemen Pusdiklat, 2 orang staf pada bagian Personalia, dan 4 orang karyawan alumni peserta pelatihan.

\section{Teknik Pengumpulan Data}

Pengumpulan data dilakukan melalui wawancara dengan pihak-pihak terkait, melakukan observasi untuk merekam rangkaian proses dalam kegiatan pelatihan, serta melakukan studi literatur dengan mempelajari dokumen, SOP dan peraturan terkait lainnnya yang mengatur pelaksanaan kegiatan pendidikan dan pelatihan terhadap karyawan perusahaan.

\section{Tahapan Penelitian}

Sebagaimana pendekatan waterfall yang digunakan dalam perancangan sistem ini maka penliti membagi rangkaian kegiatannya ke dalam fase dan tahapan-tahapan pekerjaan sebagai berikut :

a. Reqirement Analysis

Pada fase ini diakukan identifikasi secara komprehensif terhadap seluruah kebutuhan dan aspek teknis lainnya dalam merancang sistem informasi training termasuk spesifikasi teknis sistem yang dibutuhkan dan disepakati oleh perancang bersama-sama dengan pengguna.

b. Sistem Design

Tahap ini dilakukan sebelum melakukan pemorgraman (coding). Pada tahap ini dilakukan dengan melakukan pemodelan menggunakan alat bantu seperti Data Flow Diagran, Entity Relationship Diagram, Flow of Document, Rancangan database, Dialog input output, dll.

c. Implementation

Dalam tahap ini mulai dilakukan pemrograman. Adapun modul dalam sistem informasi training ini meliptui modul calon peserta training/karyawan, modul peserta training, modul jenis training, dan modul reporting.

d. Integration \& Testing

Pada tahap ini dilakukan penggabungan modul-modul yang sudah dibuat dan dilakukan pengujian ini dilakukan untuk mengetahui apakah software yang dibuat telah sesuai dengan desain awal yang di sepakati termasuk potensi masih ada dan tidaknya kesalahan operasi dan kesalahan logika yang terjadi.

e. Operation \& Maintenance

Ini merupakan tahap akhir pembangunan sistem informasi training. Software yang telah operasikan kemudian dilakukan perbaikan jika terdapat kesalahan pada langkah sebelumnya.

\section{Hasil dan Pembahasan}

Berdasarkan hasil analis dan studi kelayakan beserta data dan informasi yang berhasil dikumpulkan, selanjutnya dimulai pembuatan rancangan sistem sebagai acuan bagi pemrogram sekaligus sebagai alat dokumentasi atas sistem yang dirancang. Beberapa alat bantu pemodelan yang digunakan meliputi : 
1. Flow of Document (FOD)

Bagan berikut merupakan bagan alir dokumen dari Sistem Informasi Training. Melalui FOD ini tergambar dengan jelas bagaimana aliran dokumen antar entitas terjadi. Setiap pelaksanaan kegiatan pelatihan diawali dengan terbitnya kalender pelatihan yang dilanjutkan dengan pemberitahuan kepada calon peserta dari departemen lain melalui pengisian formulir F1, data calon kemudian diseleksi sampai dengan rilis calon peserta diterima dan mendapat persetujuan pimpinan, fase paling akhir adalah melakukan pencetakan sertifikat peserta. Gambar FOD ditunjukkan pada Gambar 1.

\section{Context Diagram}

Rancangan sistem diawali dengan pembuatan model dalam bentuk diagram konteks dengan 3 buah simbol didalamnya yakni kotak sudut tumpul sebagai proses, kotak persegi panjang sebgai entitas, dan anak panak menunjukkan aliran data. Diagram ini berguna untuk memperoleh gambaran umum bagaimana model proses dan aliran data terjadi di dalam Sistem. Diagram Konteks dari Sistem Informasi Training dapat dilihat pada Gambar 2.

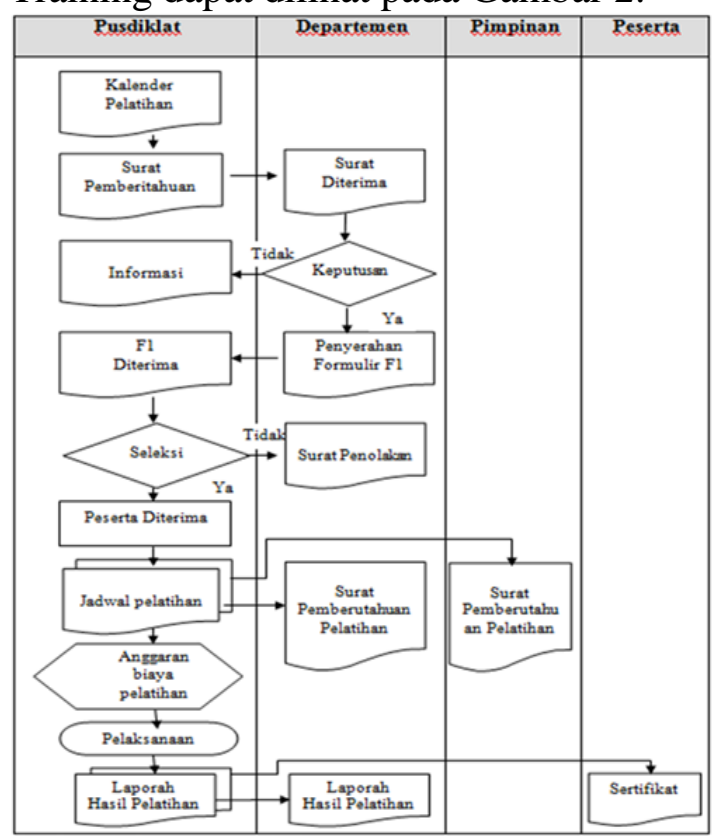

Gambar 1. Flow of Document Sistem Informasi Training

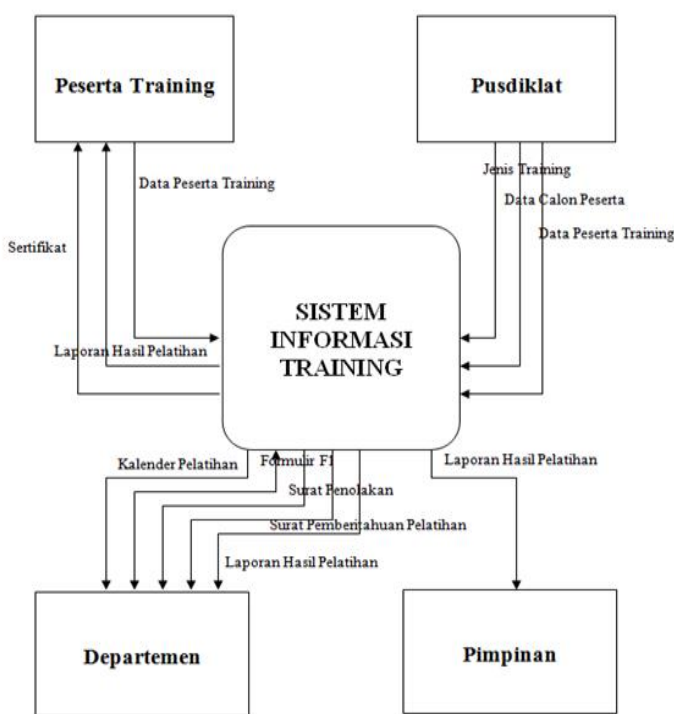

Gambar 2. Context Diagram Sistem Informasi Training

3. Entity Relationship Diagram (ERD) Jika pada Diagram Konteks dan DFD memetakan bagaimana setiap data/dokumen mengalir dari dan ke proses di dalam sistem, Entity Relationship (ERD) digunakan untuk menggambarkan relasi diantara data (penyimpanan data) yang saling terkait serta bagaimana sifat relasi diantaranya data tersebut, adapaun ERD dari Sistem Informasi Training dapat digambarkan sebagai berikut :

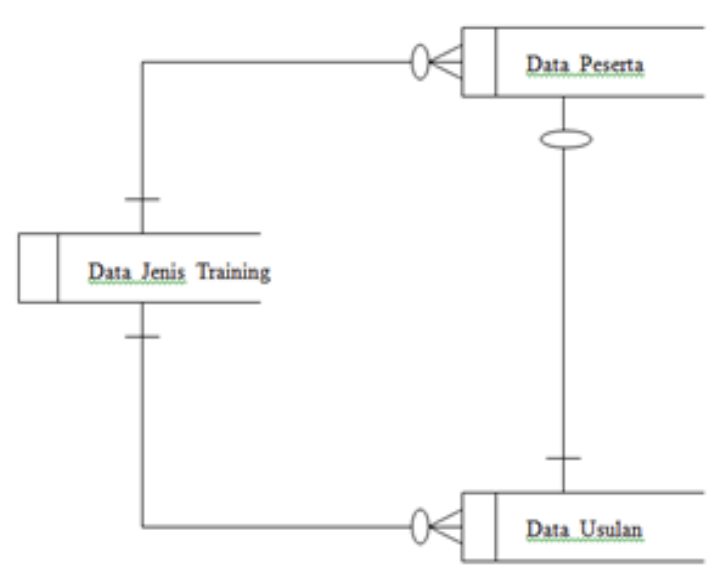

Gambar 3. Entity Relationship Diagram Sistem Informasi Training

4. Form Input Sistem

Form input pada Sistem Informasi Training ini digunakan sebagai antar 
muka oleh pengguna atau operator agar dapat berinteraksi dengan mudah melalui aplikasi. Form ini berfungsi untuk menangani pekerjaan yang terkait dengan kegiatan input data yang akan di rekam ke dalam aplikasi. Form input dari Sistem informasi training terdiri atas :

a. Form Data Usulan Pelatihan

Form data calon peserta digunakan untuk mengiinputkan / menambahkan data calon peserta yang akan diusulkan mengikuti pelatihan.

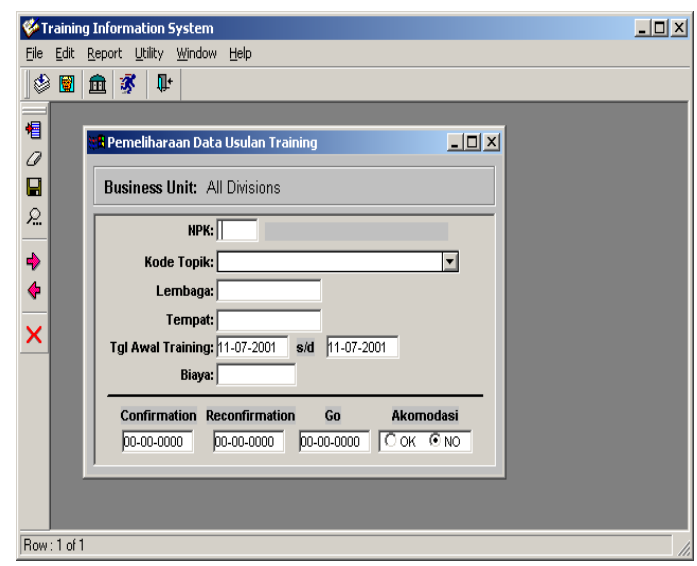

Gambar 4. Form Input Data Usulan Pelatihan

b. Form Data Peserta Pelatihan

Form ini digunakan untuk menginputkan data calon usulan yang terpilih ke dalam Sistem.

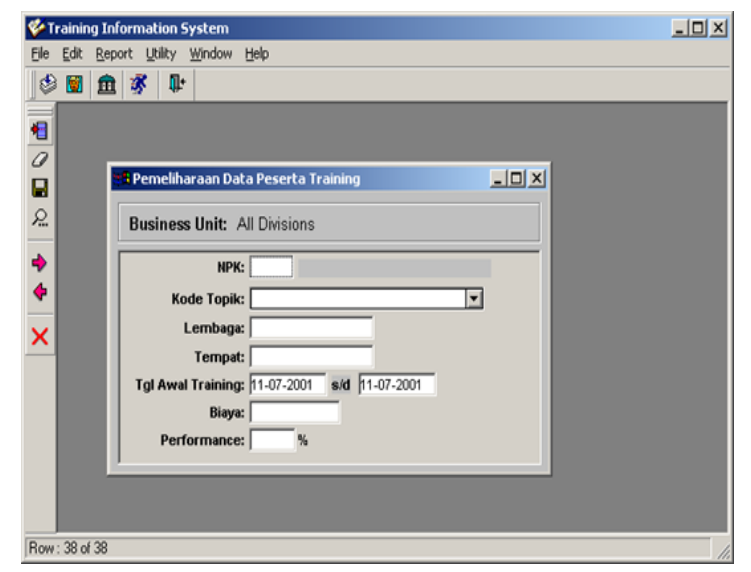

Gambar 4. Desain Input Pemeliharaan Data Peserta Pelatihan

c. Form Data Jenis Training

Form ini dipergunakan untuk menginput jenis-jenis pelatihan yang akan diselenggarakan oleh pusdiklat.

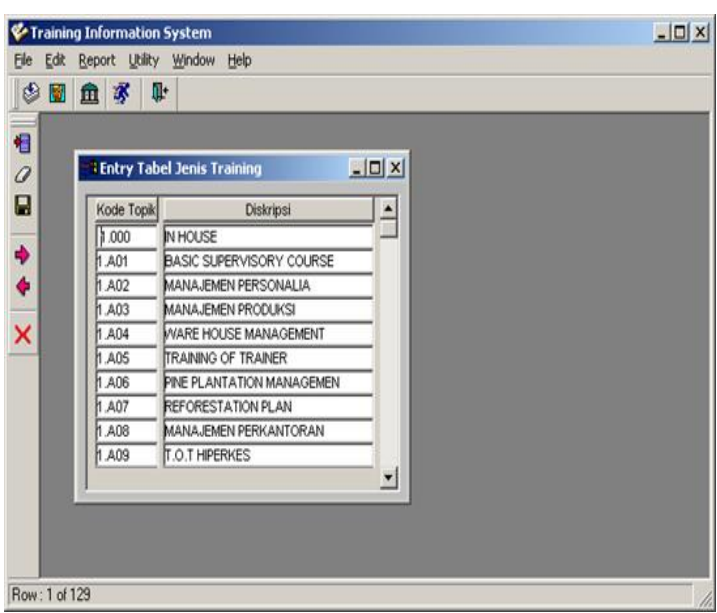

Gambar 5. Desain Input Entry Tabel Jenis Pelatihan

\section{Form Output Sistem}

Form ini digunakan untuk menampilkan dan menyajikan keluaran/output dari Sistem Informasi Training. Form output dari aplikasi ini terdiri atas beberapa jenis sebagaimana rancangan berikut :

a. Desain Output Data Usulan Peserta Pelatihan

Form output ini berisi rekapitulasi peserta yang diusulkan ke dalam pelatihan bedasarkan jenis pelatihan tertentu.

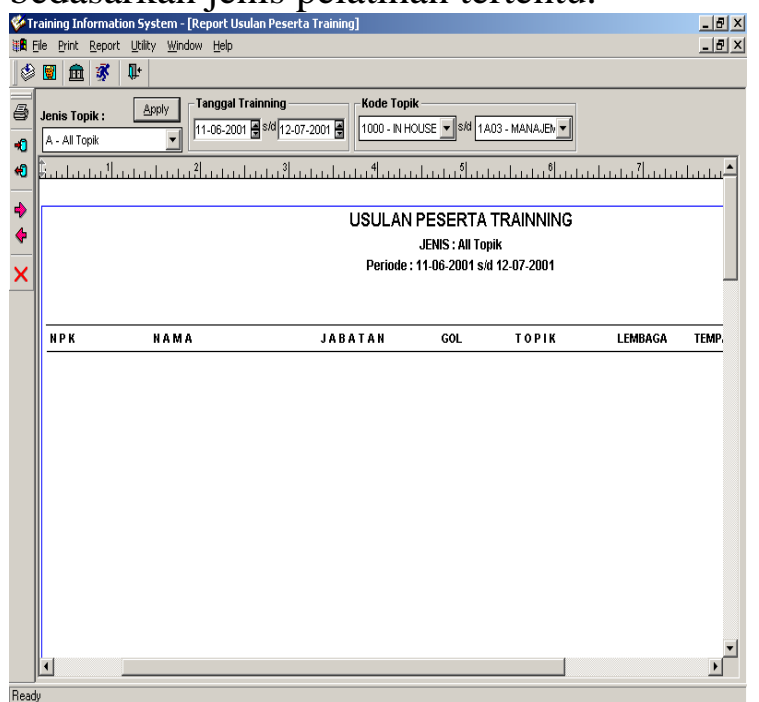

Gambar 6. Desain Output Data Usulan Peserta Pelatihan

b. Desain Output Peserta Pelatihan

Data usulan telah diverifikasi oleh penyelenggaran dan disetujui selanjutkan akan ditampilkan datanya sebagai peserta training dalam format pelaporan sebagaimana Gambar 7 berikut: 


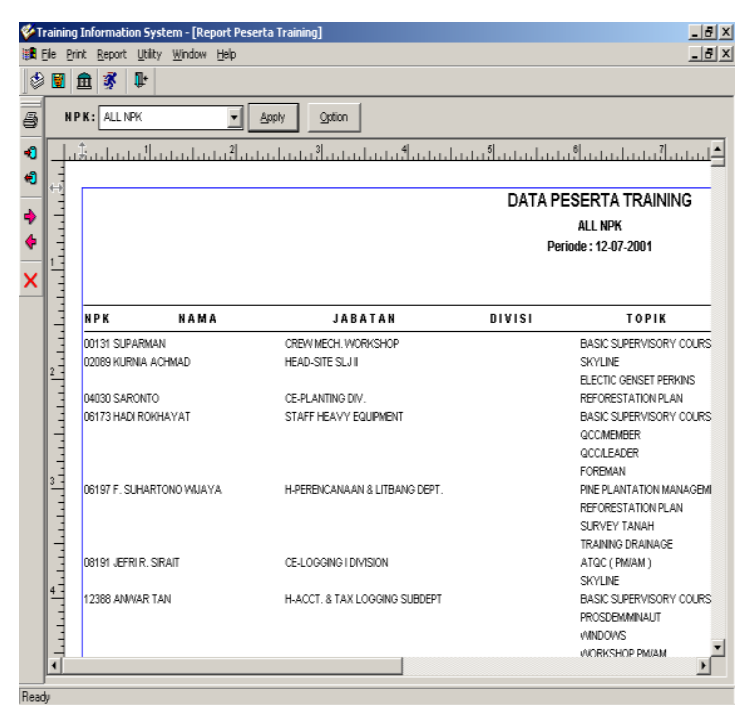

Gambar 7. Desain Output Data Peserta Pelatihan

c. Desain Output Status Usulan Pelatihan

Selanjutnya pihak pusdiklat, manejemen serta unit pengusul dapat melakukan monitoring setiap usulan peserta training dengan mudah melalui laporan status usulan training sehingga dapat terkontrol dengan mudah pergerakan data dalam proses pengajuan sampai pelaksanaannya sebagai berikut:

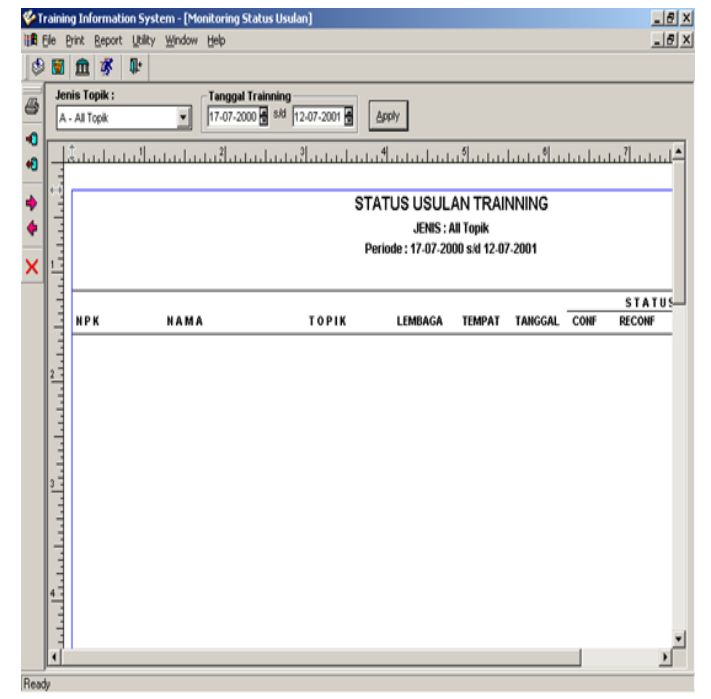

\section{Gambar 8. Desain Output Status Usulan} Pelatihan

d. Desain Output Data Peserta Pelatihan per Peserta

Sistem juga menyediakan fasilitas untuk melihat data peserta perorangan meliputi biodata peserta yang bersangkutan yaitu Nomor Pokok Karyawan, pendidikan, golongan, departemen, tempat dan tanggal lahir, tanggal masuk kerja, lokasi pekerjaan, jabatan serta jenis pelatihan yang pernah diikuti oleh peserta tersebut.

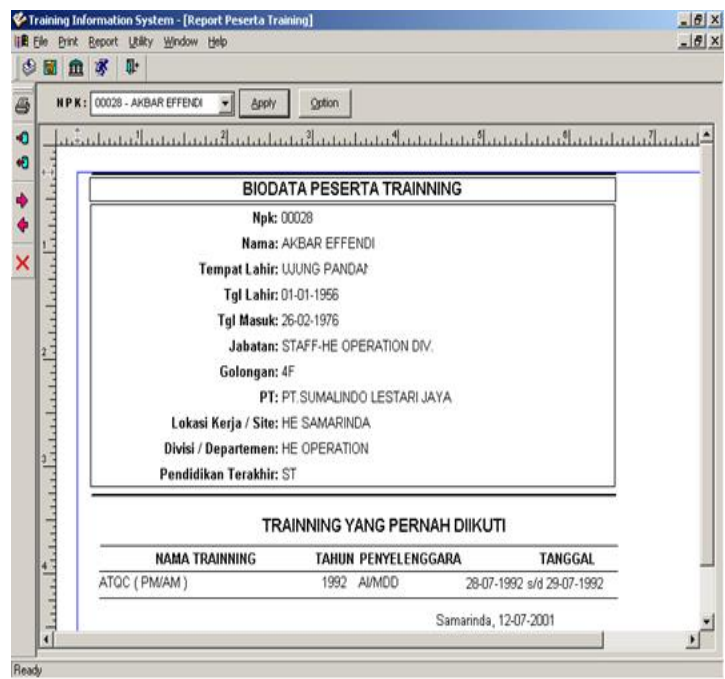

Gambar 9. Desain Output Biodata Peserta Pelatihan

e. Desain Output Biaya Pelatihan

Aplikasi juga menyajikan laporan beban biaya yang ditanggung oleh peserta guna mempersiapkan anggaran biaya nya maupun untuk mengetahui secara kumulatif besarnya biaya dalam penyelenggaraan suatu jenis pelatihan tertentu.

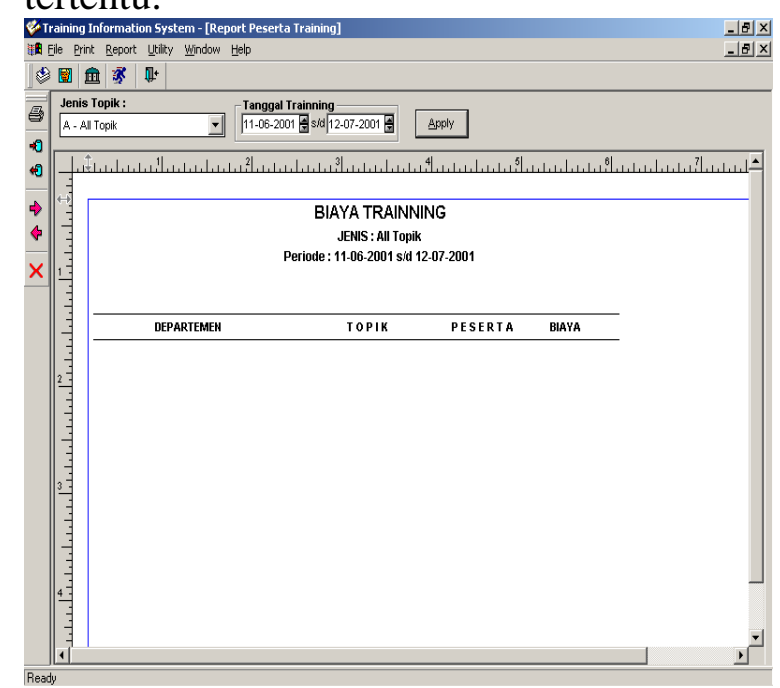

Gambar 10. Desain Output Biaya Pelatihan

6. Uji Coba dan Impelementasi Sistem Setelah dilakukan uji coba dan mengimplementasikan sistem pada penyelenggaraan pelatihan Kesehatan dan Keselamatan Kerja (K3) di Departemen 
Pusdiklat yang dilaksanakan pada bulan Februari 2020 dengan jumlah peserta sebanyak 20 orang dari berbagai departemen yakni Departemen Produksi, SDP, HTI, Plymill, Logging, Accounting, Personalia, Purchasing, Log Control, dan departemen Inventory, dapat dibuat tabel perbandingan sebelum dan setelah menggunakan sistem informasi sebagai berikut:

Tabel 1. Perbandingan sebelum dan setelah menggunakan sistem informasi

\begin{tabular}{|c|c|c|c|}
\hline \multirow{2}{*}{$\begin{array}{l}\mathrm{N} \\
\mathrm{O} .\end{array}$} & \multirow{2}{*}{$\begin{array}{c}\text { Jenis Kegiatan/ } \\
\text { Pekerjaan }\end{array}$} & \multicolumn{2}{|c|}{ Perbedaan Metode } \\
\hline & & Sebelum & Setelah \\
\hline 1. & $\begin{array}{l}\text { Membuat dan } \\
\text { membagikan } \\
\text { edaran } \\
\text { pemberitahuan } \\
\text { rencana } \\
\text { training ke } \\
\text { setiap } \\
\text { departemen/ba } \\
\text { gian }\end{array}$ & $\begin{array}{l}\text { Surat } \\
\text { edaran } \\
\text { dicetak dan } \\
\text { dikirim } \\
\text { dalam } \\
\text { bentuk hard } \\
\text { copy }\end{array}$ & $\begin{array}{l}\text { Surat } \\
\text { edaran } \\
\text { digital } \\
\text { melalui } \\
\text { aplikasi }\end{array}$ \\
\hline 2. & $\begin{array}{l}\text { Menyusun } \\
\text { jadwal } \\
\text { pelaksanaan } \\
\text { pelatihan }\end{array}$ & $\begin{array}{l}\text { Jadwal } \\
\text { disusun dan } \\
\text { dibagi } \\
\text { dalam } \\
\text { bentuk hard } \\
\text { copy }\end{array}$ & $\begin{array}{l}\text { Jadwal } \\
\text { dilihat } \\
\text { disusun } \\
\text { dan dapat } \\
\text { dilihat } \\
\text { melalui } \\
\text { sistem }\end{array}$ \\
\hline 3. & $\begin{array}{l}\text { Menyusun dan } \\
\text { mengajukan } \\
\text { anggaran } \\
\text { pelatihan }\end{array}$ & $\begin{array}{l}\text { Informasi } \\
\text { anggaran } \\
\text { pelatihan } \\
\text { per jenis } \\
\text { kegiatan } \\
\text { tersimpan } \\
\text { dalam } \\
\text { bentuk } \\
\text { dokumen } \\
\text { secara fisik }\end{array}$ & $\begin{array}{l}\text { Anggaran } \\
\text { pelatihan } \\
\text { per jenis } \\
\text { kegiatan } \\
\text { dapat } \\
\text { dimonitor } \\
\text { secara } \\
\text { digital di } \\
\text { sistem }\end{array}$ \\
\hline 4. & $\begin{array}{l}\text { Menyusun dan } \\
\text { membuat } \\
\text { laporan } \\
\text { pelaksanaan } \\
\text { training: } \\
\text { - Laporan } \\
\quad \text { Calon } \\
\text { Peserta } \\
\text { Training } \\
\text { - Laporan } \\
\text { Peserta } \\
\text { - Laporan } \\
\text { Peserta per } \\
\text { Jenis } \\
\text { Training } \\
\text { - Laporan } \\
\end{array}$ & $\begin{array}{l}\text { Semua } \\
\text { laporan } \\
\text { terkait } \\
\text { pelaksanaan } \\
\text { training } \\
\text { disusun } \\
\text { secara } \\
\text { terpisah dan } \\
\text { manual } \\
\text { menggunka } \\
\text { n MS } \\
\text { Excell dan } \\
\text { MS Word } \\
\text { serta di } \\
\text { cetak dan } \\
\text { disajikan }\end{array}$ & $\begin{array}{l}\text { Laporan } \\
\text { terkait } \\
\text { pelaksana } \\
\text { an } \\
\text { training } \\
\text { telah } \\
\text { tersedia } \\
\text { dan } \\
\text { terformat } \\
\text { di sistem } \\
\text { dan dapat } \\
\text { diunduh } \\
\text { setiap } \\
\text { saat. }\end{array}$ \\
\hline
\end{tabular}

\begin{tabular}{|c|c|c|c|}
\hline & $\begin{array}{l}\text { Biaya } \\
\text { Training }\end{array}$ & $\begin{array}{l}\text { secara } \\
\text { manual }\end{array}$ & \\
\hline 5. & $\begin{array}{l}\text { Pembuatan } \\
\text { Sertifikat } \\
\text { Peserta }\end{array}$ & $\begin{array}{l}\text { Dilayout, } \\
\text { dicetak, dan } \\
\text { didistribusi } \\
\text { kan secara } \\
\text { manual } \\
\text { dalam } \\
\text { bentuk fisik }\end{array}$ & $\begin{array}{l}\text { Template } \\
\text { sertifikat } \\
\text { peserta } \\
\text { telah } \\
\text { tersedia } \\
\text { di Sistem } \\
\text { dan dapat } \\
\text { diunduh } \\
\text { secara } \\
\text { digital }\end{array}$ \\
\hline
\end{tabular}

\section{Simpulan}

Penelitian yang dilakukan pada departemen Pusdiklat menghasilkan sebuah perangkat lunak Sistem Informasi Training yang digunakan dalam membantu pengelolaan kegiatan pendidikan dan pelatihan mulai dari kegiatan seleksi calon peserta, penjadwalan kegiatan, tata kelola administrasi pelaksanaan, perencanaan anggaran dan pembiayaan, sampai dengan evaluasi dan kegiatan pelaporan. Berdasarkan data perbandingan pola pengelolaan sebelum dan setelah menggunakan sistem dapat disimpulkan bahwa Sistem Informasi Training dapat meningkatkan efisiensi dan efektifitas dalam mengelola kegiatan training.

\section{Daftar Pustaka}

Andriana, I. dan Asari, W.F. (2017). Perancangan Sistem Pelatihan Berbasis Web. Prosiding Seminar Nasional Komputer dan Informatika (SENASKI), 89-94. Bandung: Jurusan Teknik Komputer dan Teknik Informatika Universitas Komputer Indonesia.

Setiyani, L. (2018). Perancangan Sistem Informasi Pendidikan dan Pelatihan (Diklat) di Balai Besar Pelatihan Kesehatan Ciloto. Jurnal Interkom, 13(1), 18-27.

Sudjana, Nana. (1990). Penilaian Hasil Proses Belajar Mengajar.

Bandung: PT Remaja Rosdakarya.

Sommerville, Ian. (2016). Software Engineering. Tenth edition, Global 
edition. Always Learning. Boston Columbus Indianapolis New York San Francisco Hoboken Amsterdam Cape Town Dubai London Madrid Milan Munich Paris Montreal Toronto Delhi Mexico City São Paulo Sydney Hong Kong Seoul Singapore Taipei Tokyo: Pearson.

Somya, R. and Nathanael, T.M. E. (2019). Pengembangan Sistem Informsi Pelatihan berbasis Web Menggunakan Teknologi Web Service dan Framework Laravel. Jurnal Techno Nusa Mandiri 16(1): 51-58.

http://doi.org/10.33480/techno.v16i 1.164.

Sugiyono. (2016). Penelitian Pendidikan Pendekatan Kuantitatif, Kualitatif, Dan R\&D. Bandung: Alfabeta. 